Research

Open Access

\title{
Treatment of candidemia and invasive candidiasis in the intensive care unit: post hoc analysis of a randomized, controlled trial comparing micafungin and liposomal amphotericin B
}

Bertrand F Dupont ${ }^{1}$, Olivier Lortholary ${ }^{1,2}$, Luis Ostrosky-Zeichner ${ }^{3}$, Flavie Stucker ${ }^{4}$ and

Vijay Yeldandi5

\author{
1Université Paris Descartes, Hôpital Necker-Enfants Malades, Centre d'Infectiologie Necker-Pasteur, 149 rue de Sevres, 75015 Paris, France \\ ${ }^{2}$ Centre National de Référence Mycologie et Antifongiques, Institut Pasteur (CNRS URA3012), 25 rue du Docteur Roux, 75724 Paris, France \\ 3University of Texas, 6431 Fannin St, John Freeman Building, Houston, TX 77030, USA \\ ${ }^{4}$ Astellas Pharma BV, Elisabethhof 19, 2353 EW Leiderdorp, The Netherlands \\ ${ }^{5}$ Westlake Hospital, 1111 Superior Street, SUITE 101, Melrose Park, IL 60160, USA \\ Corresponding author: Bertrand F Dupont, bertrand.dupont@nck.aphp.fr
}

Received: 10 Jul 2009 Revisions requested: 29 Jul 2009 Revisions received: 27 Aug 2009 Accepted: 5 Oct 2009 Published: 5 Oct 2009

Critical Care 2009, 13:R159 (doi:10.1186/cc8117)

This article is online at: http://ccforum.com/content/13/5/R159

(C) 2009 Dupont et al.; licensee BioMed Central Ltd.

This is an open access article distributed under the terms of the Creative Commons Attribution License (http://creativecommons.org/licenses/by/2.0), which permits unrestricted use, distribution, and reproduction in any medium, provided the original work is properly cited.

\begin{abstract}
Introduction Invasive candidiasis and candidemia are lifethreatening nosocomial infections in intensive care patients.

Methods A post hoc analysis of a phase 3 trial assessing micafungin (100 mg/day for subjects $>40 \mathrm{~kg} ; 2 \mathrm{mg} / \mathrm{kg} /$ day for subjects $\leq 40 \mathrm{~kg}$ ) versus liposomal amphotericin B (3 mg/kg/ day). Subgroups were defined according to the type of ward on the first day of treatment: intensive care unit (ICU) or non-ICU. Multivariate regression was performed to identify factors associated with treatment success at end of therapy and allcause mortality at days 8 and 30 .
\end{abstract}

Results In non-ICU subjects, treatment success was significantly higher for micafungin versus liposomal amphotericin B (85\% ( $n=108 / 127)$ versus $72.1 \%(n=98 /$ 136); $P=0.0113$ ). However, for ICU subjects, treatment success rates for micafungin versus liposomal amphotericin $B$ were similar $(62.5 \%(n=75 / 120)$ versus $66.4 \%(n=73 / 110)$; $P=0.5828$ ). Overall, treatment success was significantly lower in ICU subjects compared with non-ICU subjects $(64.3 \%(n=$ $148 / 230)$ versus $78.3 \%(n=206 / 263) ; P=0.0006)$. Multivariate regression analysis revealed a lower likelihood of treatment success for: ICU versus non-ICU subjects; persistent neutropenia; and high versus low Acute Physiology and Chronic
Health Evaluation (APACHE) II scores. However, when interactions between potential explanatory factors were included in the analysis model, ICU status no longer emerged as a significant associated variable but the association between APACHE II score and treatment outcome remained. Further analyses indicated that the likelihood of mortality at day 8 and day 30 was lower for subjects with lower APACHE II scores. Renal function was significantly better in micafungin versus liposomal amphotericin B subjects: a difference (liposomal amphotericin B - micafungin in mean peak change in estimated glomerular filtration rate $\left(\mathrm{ml} /\right.$ minute/1.73 $\left.\mathrm{m}^{2}\right)$ of $-18.2(P<$ $0.0001)$ and $-17.7(P=0.0124)$ in non-ICU and ICU subjects, respectively.

Conclusions Overall, ICU subjects had lower treatment success rates than non-ICU subjects for both liposomal amphotericin $\mathrm{B}$ and micafungin. Multivariate regression after controlling for potential confounding factors suggested the APACHE II score remained a potential explanatory factor associated with treatment success, mortality at day 8 , and mortality at day 30 .

Trial registration Post hoc analysis - clinicaltrials.gov trial NCT00106288. 


\section{Introduction}

Invasive Candida infections occur more often in patients housed inside rather than outside an intensive care unit (ICU) $[1,2]$, with reported rates of candidemia ranging from 2 to almost 10 per 1,000 hospital ICU admissions. This increased incidence of invasive Candida infections in ICU patients is important because logistic regression analyses of data from observational studies suggest that Candida infection is an independent predictor of mortality among ICU patients, and both hospitalization and length of stay in an ICU are predictors of poor outcomes among patients with candidemia [3-8].

Candida epidemiology has changed as infections due to nonalbicans Candida species have increased [9]. This shift in the prevalence of Candida species is a matter of concern because species such as Candida glabrata have been associated with reduced susceptibility to triazole antifungals [10-14].

The relatively high rate of infection by Candida spp. in ICUs, the increasing prevalence of non-albicans Candida spp., and the associated mortality suggest that new treatment approaches are required. One such approach may be the empirical use of antifungal agents that provide broad-spectrum coverage against Candida spp. [10,11,14-16]. Findings from numerous prospective and retrospective studies indicate that optimizing and reducing the delay of antifungal therapy reduces attributable mortality in patients with candidemia whereas inappropriate antifungal therapy is a significant predictor of mortality [3,17-20]. As a consequence of such findings, the most recent update to the guidelines of the Infectious Diseases Society of America includes a recommendation for the use of an echinocandin for the initial management of moderately severe to severe episodes of invasive candidiasis [14].

Micafungin is a novel echinocandin antifungal agent, which has demonstrated in vitro fungicidal activity against all clinically important species of Candida including those with resistance to fluconazole [21-27]. In two phase 3 trials, micafungin demonstrated non-inferiority to both caspofungin and liposomal amphotericin B for the treatment of invasive candidiasis and candidemia, and showed better tolerability compared with liposomal amphotericin B $[28,29]$.

We conducted a post hoc analysis of the phase 3 study comparing micafungin with liposomal amphotericin B to explore the association between potential explanatory variables and clinical outcomes in adult patients who initiated antifungal chemotherapy in an ICU or in a non-ICU ward [29].

\section{Materials and methods Study objectives and design}

The present study was a post hoc analysis of a double-blind, randomized, non-inferiority study conducted by the Micafungin Invasive Candidiasis Working Group at 115 medical centers worldwide from January 2003 to November 2004. The primary objective of this present analysis was to determine whether an ICU stay was associated with the following outcomes in patients treated for candidemia and invasive candidiasis: overall treatment success; mycological response; and all-cause mortality at day 8 and day 30 post treatment initiation. The full methodology of the study has been published previously [29]. Adult patients (age $\geq 16$ years) were eligible if they had clinical signs (that is, fever, hypothermia, hypotension, local signs and symptoms of inflammation, radiologic evidence) of systemic Candida infection, and had one or more positive Candida cultures from blood or another sterile site within the previous 4 days.

Subjects were randomized to receive either micafungin (100 $\mathrm{mg} /$ day for patients $>40 \mathrm{~kg} ; 2 \mathrm{mg} / \mathrm{kg}$ for patients $\leq 40 \mathrm{~kg}$ ) or liposomal amphotericin B (3 $\mathrm{mg} / \mathrm{kg}$ per day) as first-line treatment of candidemia and invasive candidiasis. During random assignment to their respective treatment regimens, patients were stratified by study center and neutropenia status but not by whether or not Candida infection developed inside or outside an ICU.

Antifungal therapy was prescribed for a minimum treatment period of 14 days and a maximum treatment period of 4 weeks - except for patients with chronic disseminated candidiasis, Candida osteomyelitis, or Candida endocarditis, for whom the study drug could be administered for up to 8 weeks. While patients with neutropenia who received antifungal prophylaxis prior to the beginning of the study were eligible, non-neutropenic patients who had received 3 days or more of systemic antifungal therapy within the previous week were ineligible. The initial doses of study drugs remained fixed during the first 5 days of treatment but a dosage increase (up to $200 \mathrm{mg} /$ day for micafungin and up to $5 \mathrm{mg} / \mathrm{kg} /$ day for liposomal amphotericin B) was allowed if there was mycological persistence or ongoing clinical and radiographic evidence of infection. Conversely, a dose decrease of $50 \%$ for liposomal amphotericin $B$ was indicated for drug-related nephrotoxicity.

Clinical and mycological assessments were made at baseline immediately prior to treatment initiation (study day 0 ), three times weekly during the treatment phase, and at the end of therapy. Assessments were continued at prespecified intervals post therapy for patients who were suspected of having a recurrent or emergent infection.

The study was approved by ethics committees of the participating centers, and all patients gave written, informed consent for their participation.

\section{Analysis population}

The analysis populations consisted of all patients included in the modified intent-to-treat populations, defined as all subjects who received at least one dose of micafungin or liposomal amphotericin B and had a confirmed Candida infection at 
baseline. Subjects were retrospectively assigned to the ICU subgroup if they stayed in the ICU for at least 1 day during study days -1 to 3 .

\section{Analysis endpoints}

The analysis endpoints were as follows: overall treatment success, defined as success in both clinical response and mycological response (success in clinical response at the end of therapy defined as a complete or partial resolution of symptoms); mycological response, defined as eradication or presumed eradication of the baseline pathogen; and all-cause mortality at day 8 and day 30 post treatment initiation. A patient death during therapy was defined as treatment failure. During therapy was defined as from the date of the first dose to 1 day after the last dose.

\section{Statistical modeling}

A series of univariate analyses were performed to evaluate associations between each treatment outcome and the ICU status. Fisher's exact test was applied for overall treatment success, mycological response, and all-cause mortality at day 8 and day 30 . Potential explanatory variables (Table 1) were

Table 1

Exploratory variables used in the multivariate analyses

\begin{tabular}{|c|c|}
\hline Class & Study value \\
\hline \multirow[t]{2}{*}{ Treatment group } & Micafungin $100 \mathrm{mg} /$ day \\
\hline & Liposomal amphotericin B 3 mg/kg/day \\
\hline Age (years) & Continuous \\
\hline \multirow[t]{2}{*}{ Sex } & Female \\
\hline & Male \\
\hline \multirow[t]{2}{*}{ Region } & Brazil, Europe, India, North America \\
\hline & Other \\
\hline \multirow[t]{4}{*}{ Race } & Caucasian \\
\hline & Asian-Indian \\
\hline & Black \\
\hline & Other \\
\hline \multirow[t]{2}{*}{ Primary diagnosis } & Candidemia \\
\hline & Disseminated candidiasis \\
\hline \multirow[t]{4}{*}{ Organism } & Candida albicans only versus non-albicans Candida \\
\hline & $\begin{array}{l}\text { C. albicans, Candida tropicalis, Candida parapsilosis, Candida glabrata versus other } \\
\text { Candida spp. }\end{array}$ \\
\hline & Candida parapsilosis versus other Candida spp. \\
\hline & Candida krusei versus other Candida spp. \\
\hline Neutropenia ${ }^{a}$ at baseline & Yes/No \\
\hline Persistent neutropenia & Yes/No \\
\hline Liver disorder/failure & Yes/No \\
\hline Renal disorder/failure & Yes/No \\
\hline Antibiotic use & Yes/No \\
\hline Diabetes mellitus & Yes/No \\
\hline Solid organ transplant & Yes/No \\
\hline Corticosteroid therapy & Yes/No \\
\hline \multirow[t]{2}{*}{ Catheter status ${ }^{b}$} & Removed within 48 hours of treatment initiation, Yes/No \\
\hline & Removed at any time during the study, Yes/No \\
\hline Acute Physiology and Chronic Health Evaluation II score & Continuous \\
\hline
\end{tabular}

aAbsolute neutrophil count $<500$ cells/ $\mu$ l. b Explanatory variable used in analysis of candidemic patients only. 
investigated to assess their effect on treatment outcomes. Fisher's exact test was applied if the explanatory factor was a discrete variable and the Wilcoxon rank sum test was used if the explanatory factor was a continuous variable. Explanatory variables with $P \leq 0.1$ were selected as potential confounding factors in the final multivariate models, described below as a logistic regression model.

The effects of ICU status on overall treatment success, mycological response, and all-cause mortality at day 8 and day 30 were evaluated using logistic regression analysis. The logistic regression model used can be described as:

$$
\log i t(p)=\log \left(\frac{p}{1-p}\right)=\alpha+\beta^{\prime} X
$$

where $p$ is the probability of treatment success, $\alpha$ is the interception, $X$ is the vector of explanatory variables, and $\beta$ is the parameter vector to be estimated.

The ICU status and all identified potential confounding factors were included in the model as first-order explanatory variables. For each individual variable, the effect of the variable on treatment outcome in the multivariate model was tested by the Wald chi-square test. From the model, treatment outcome was compared between the levels of the variable using the odds ratio and the $95 \%$ Wald confidence interval.

\section{Results}

\section{Baseline patient characteristics}

Of the 537 adult subjects (age $\geq 16$ years) enrolled and randomized to receive treatment with micafungin or liposomal amphotericin B, 494 subjects were included in the modified intent-to-treat analysis. Subjects were evenly distributed between the ICU $(n=263)$ and other hospital wards $(n=230)$ at the time of treatment initiation, with one subject recorded as ICU status unknown. The micafungin and liposomal amphotericin B treatment groups were well matched with respect to the proportion of assigned subjects in an ICU (48.6\% versus $44.7 \%$, respectively). Table 2 summarizes the baseline demographics and clinical characteristics of the analysis population, categorized by ICU status and treatment group.

While age and sex were well matched across the subgroups, there was a disparity in the racial composition of the ICU and non-ICU groups in this worldwide study. The percentage of Black subjects in the ICU group was less than that in the nonICU group (2.2\% versus $6.8 \%$ ), and the prevalence of races other than Black or Caucasian were nearly twice as high in the ICU group as in the non-ICU group (45.2\% versus $24.3 \%$ ). There was a higher proportion of subjects from Brazil in the non-ICU group and a higher proportion of subjects from India in the ICU group.
With a few exceptions, the proportions of subjects with underlying conditions or risk factors predisposing to a nosocomial Candida infection were similar across the ICU and non-ICU subgroups. As expected, the mean (18.1 versus 13.8) and median (17.5 versus 14.0) Acute Physiology and Chronic Health Evaluation (APACHE) II scores were higher in the ICU group than in the non-ICU group. In addition, the presence of a central venous catheter at baseline was more frequent in the ICU group (96.1\% versus $71.8 \%$ ), whereas baseline neutropenia was more common in non-ICU subjects $(17.9 \%$ versus $4.3 \%)$. The length of hospital stay was similar across both subgroups.

There were no substantial differences between the micafungin and liposomal amphotericin B treatment groups for ICU and non-ICU subjects. Candidemia was more common than invasive candidiasis in the present study, and the prevalence of these primary diagnoses was well matched between micafungin-treated and liposomal amphotericin B-treated subjects and across the ICU and non-ICU subgroups (Table 3 ).

Overall and across the analysis groups, a non-albicans Candida species was more frequently isolated at baseline than Candida albicans. The rank order of prevalence of baseline Candida spp. was identical across the subgroups. Although the between-group prevalence of causative pathogens was similar, it was noted in liposomal amphotericin B-treated subjects that Candida krusei was isolated at baseline more frequently in non-ICU subjects (including three patients who had an underlying hematological disorder) compared with ICU subjects; nine isolates versus one isolate, respectively.

\section{Efficacy outcomes}

Rates of overall treatment success, of mycological response, and of all-cause mortality for ICU and non-ICU subjects treated with micafungin or liposomal amphotericin B are summarized in Table 4. In non-ICU subjects, the treatment success rate was significantly higher among subjects receiving micafungin than liposomal amphotericin B (85\% versus $72.1 \% ; P=0.0113$ ). For ICU subjects, however, treatment success rates for micafungin versus liposomal amphotericin $B$ were similar (62.5\% versus $66.4 \%$, respectively).

Rates of mycological response were slightly higher than rates of overall treatment success, and were consistent across both ICU subgroups and across each treatment group. All-cause mortality at day 8 was moderate $(7.6 \%$ in non-ICU subjects and $18.7 \%$ in ICU subjects) but increased by day $30(21.7 \%$ in non-ICU subjects and $36.5 \%$ in ICU subjects). KaplanMeier estimates of the probability of survival in ICU and nonICU subjects treated with micafungin and liposomal amphotericin $\mathrm{B}$ are displayed in Figure 1.

When the micafungin treatment group and the liposomal amphotericin B treatment group were combined and the data 
Table 2

\begin{tabular}{|c|c|c|c|c|c|c|}
\hline \multirow[t]{2}{*}{ Characteristic } & \multicolumn{2}{|l|}{ Micafungin } & \multicolumn{2}{|c|}{ Liposomal amphotericin B } & \multicolumn{2}{|l|}{ Total } \\
\hline & Non-ICU $(n=127)$ & $\operatorname{ICU}(n=120)$ & Non-ICU $(n=136)$ & $\operatorname{ICU}(n=110)$ & Non-ICU $(n=263)$ & $\operatorname{ICU}(n=230)$ \\
\hline \multicolumn{7}{|l|}{ Age (years) } \\
\hline Mean \pm standard deviation & $53.1 \pm 16.90$ & $52.4 \pm 19.40$ & $53.7 \pm 18.74$ & $53.4 \pm 17.76$ & $53.4 \pm 17.85$ & $52.9 \pm 18.60$ \\
\hline Median & 54.0 & 54.5 & 55.5 & 56.0 & 55.0 & 56.0 \\
\hline Range & 18.0 to 87.0 & 18.0 to 89.0 & 16.0 to 89.0 & 17.0 to 97.0 & 16.0 to 89.0 & 17.0 to 97.0 \\
\hline Male, $n(\%)$ & $79(62.2)$ & $76(63.3)$ & $79(58.1)$ & $68(61.8)$ & $158(60.1)$ & $144(62.6)$ \\
\hline Female, $n(\%)$ & $48(37.8)$ & $44(36.7)$ & $57(41.9)$ & $42(38.2)$ & 105 (39.9) & $86(37.4)$ \\
\hline \multicolumn{7}{|l|}{ Race, $n(\%)$} \\
\hline Black & $11(8.7)$ & $2(1.7)$ & $7(5.1)$ & $3(2.7)$ & $18(6.8)$ & $5(2.2)$ \\
\hline Caucasian & $84(66.1)$ & $65(54.2)$ & $97(71.3)$ & $56(50.9)$ & $181(68.8)$ & $121(52.6)$ \\
\hline Other & $32(25.20)$ & $53(44.17)$ & $32(23.5)$ & $51(46.4)$ & $64(24.3)$ & $104(45.2)$ \\
\hline \multicolumn{7}{|l|}{ Region, $n(\%)$} \\
\hline Brazil & $37(29.1)$ & $18(15.0)$ & 42 (30.9) & 15 (13.6) & 79 (30.0) & 33 (14.3) \\
\hline Europe & $37(29.1)$ & $46(38.3)$ & $43(31.6)$ & $34(30.9)$ & $80(30.4)$ & $80(34.8)$ \\
\hline India & $12(9.4)$ & $44(36.7)$ & $20(14.7)$ & 39 (35.5) & $32(12.2)$ & $83(36.1)$ \\
\hline North America & $11(8.7)$ & $6(5.0)$ & $12(8.8)$ & $7(6.4)$ & $23(8.7)$ & $13(5.7)$ \\
\hline Other & $30(23.6)$ & $6(5.0)$ & $19(14.0)$ & $15(13.6)$ & $49(18.6)$ & $21(9.1)$ \\
\hline \multicolumn{7}{|l|}{ APACHE II score } \\
\hline $\begin{array}{l}\text { Mean } \pm \text { standard } \\
\text { deviation }\end{array}$ & $13.4 \pm 6.32$ & $18.4 \pm 9.39$ & $14.1 \pm 6.60$ & $17.8 \pm 9.35$ & $13.8 \pm 6.46$ & $18.1 \pm 9.35$ \\
\hline Median & 13.0 & 19.0 & 14.0 & 17.0 & 14.0 & 17.5 \\
\hline Range & 0 to 30.0 & 0 to 44.0 & 0 to 37.0 & 0 to 47.0 & 0 to 37.0 & 0 to 47.0 \\
\hline \multicolumn{7}{|l|}{ Relevant risk factors } \\
\hline Catheter present & $95(75.4)$ & $116(96.7)$ & $93(68.4)$ & $105(95.5)$ & $188(71.8)$ & $221(96.1)$ \\
\hline Bone marrow transplant & $4(3.1)$ & $2(1.7)$ & $2(1.5)$ & $1(0.9)$ & $6(2.3)$ & $3(1.3)$ \\
\hline Neutropenia & $26(20.5)$ & $6(5.0)$ & $21(15.4)$ & $4(3.6)$ & 47 (17.9) & $10(4.3)$ \\
\hline $\begin{array}{l}\text { Persistent neutropenia } \\
\text { during therapy }\end{array}$ & $11(8.8)$ & $3(2.5)$ & $7(5.3)$ & $2(1.9)$ & $18(7.0)$ & $5(2.2)$ \\
\hline Acute leukemia & $20(15.7)$ & $1(0.8)$ & $13(9.6)$ & $3(2.7)$ & $33(12.5)$ & $4(1.7)$ \\
\hline Hematological disorder & $37(29.1)$ & $7(5.8)$ & $24(17.6)$ & $8(7.3)$ & $61(23.2)$ & $15(6.5)$ \\
\hline Liver disorder/failure & $1(0.8)$ & $0(0.0)$ & $2(1.5)$ & $0(0.0)$ & $3(1.1)$ & $0(0.0)$ \\
\hline Pancreatitis & $5(3.9)$ & 4 (3.3) & $3(2.2)$ & $6(5.5)$ & $8(3.0)$ & $10(4.3)$ \\
\hline Renal disorder/failure & $0(0.0)$ & $2(1.7)$ & $1(0.7)$ & $0(0.0)$ & $1(0.4)$ & $2(0.9)$ \\
\hline Solid organ tumor & $23(18.1)$ & $12(10.0)$ & $27(19.9)$ & $23(20.9)$ & $50(19.0)$ & $35(15.2)$ \\
\hline Solid organ transplant & $4(3.1)$ & $9(7.5)$ & $5(3.7)$ & $4(3.6)$ & $9(3.4)$ & $13(5.7)$ \\
\hline Antibiotic use & $23(18.1)$ & $29(24.2)$ & $28(20.6)$ & $35(31.8)$ & $51(19.4)$ & $64(27.8)$ \\
\hline Corticosteroid therapy & $14(11.0)$ & $22(18.3)$ & $20(14.7)$ & $17(15.5)$ & 34 (12.9) & $39(17.0)$ \\
\hline $\begin{array}{l}\text { Other } \\
\text { immunosuppression }\end{array}$ & $9(7.1)$ & $11(9.2)$ & $8(5.9)$ & $7(6.4)$ & $17(6.5)$ & $18(7.8)$ \\
\hline Intravenous line/device & 40 (31.5) & $26(21.7)$ & $35(25.7)$ & $20(18.2)$ & 75 (28.5) & $46(20.0)$ \\
\hline \multicolumn{7}{|l|}{ Length of hospital stay } \\
\hline $\begin{array}{l}\text { Mean } \pm \text { standard } \\
\text { deviation }\end{array}$ & $21.6 \pm 17.77$ & $20.0 \pm 20.36$ & $23.2 \pm 20.35$ & $27.6 \pm 47.59$ & $22.5 \pm 19.13$ & $23.6 \pm 36.16$ \\
\hline Median & 18.0 & 14.0 & 19.5 & 15.0 & 19.0 & 14.5 \\
\hline Range & 2 to 82.0 & 1 to 126.0 & 1 to 97.0 & 1 to 388.0 & 1 to 97.0 & 1 to 388.0 \\
\hline
\end{tabular}

APACHE, Acute Physiology and Chronic Health Evaluation; ICU, intensive care unit. 
Critical Care Vol 13 No 5 Dupont et al.

Table 3

Primary diagnosis and prevalence of causative Candida species

\begin{tabular}{|c|c|c|c|c|c|c|}
\hline \multirow[t]{2}{*}{ Characteristic } & \multicolumn{2}{|l|}{ Micafungin } & \multicolumn{2}{|c|}{ Liposomal amphotericin B } & \multicolumn{2}{|l|}{ Total } \\
\hline & Non-ICU $(n=127)$ & $\operatorname{ICU}(n=120)$ & Non-ICU $(n=136)$ & $\operatorname{ICU}(n=110)$ & Non-ICU $(n=263)$ & $\operatorname{ICU}(n=230)$ \\
\hline \multicolumn{7}{|l|}{ Primary diagnosis } \\
\hline Candidemia & $109(85.8)$ & $98(81.7)$ & $115(84.6)$ & $94(85.5)$ & $224(85.2)$ & $192(83.5)$ \\
\hline Invasive candidiasis & $18(14.2)$ & $22(18.3)$ & $21(15.4)$ & $16(14.5)$ & $39(14.8)$ & $38(16.5)$ \\
\hline \multicolumn{7}{|c|}{ Isolated Candida spp. at baseline ${ }^{a}$} \\
\hline Candida albicans & $44(34.6)$ & $58(48.3)$ & $55(40.4)$ & $54(49.1)$ & 99 (37.6) & $112(48.7)$ \\
\hline Candida parapsilosis & $29(22.8)$ & $13(10.8)$ & $22(16.2)$ & $16(14.5)$ & $51(19.4)$ & $29(12.6)$ \\
\hline Candida tropicalis & $37(29.1)$ & $29(24.2)$ & $36(26.5)$ & $26(23.6)$ & $73(27.8)$ & $55(23.9)$ \\
\hline Candida glabrata & $15(11.8)$ & $15(12.5)$ & $10(7.4)$ & $9(8.2)$ & $25(9.5)$ & $24(10.4)$ \\
\hline Candida krusei & $5(3.9)$ & 4 (3.3) & $9(6.6)$ & $1(0.9)$ & $14(5.3)$ & $5(2.2)$ \\
\hline Other Candida species & $6(4.7)$ & $11(9.2)$ & $17(12.5)$ & $14(12.7)$ & $23(8.7)$ & $25(10.9)$ \\
\hline
\end{tabular}

Data presented as $n(\%)$. ICU, intensive care unit. aA patient may have had more than one Candida spp. isolated at baseline.

analyzed only according to ICU status, the results demonstrated that fewer ICU subjects achieved overall treatment success than non-ICU subjects. This difference was demonstrated to be statistically significant $(64.3 \%$ versus $78.3 \% ; P$ $=0.0006$ ).

\section{Multivariate logistic regression analyses}

Multivariate regression analyses were performed in order to uncover the risk factors underlying the difference in treatment success noted in ICU subjects versus non-ICU subjects. When the logistic regression model was run without interaction terms between potential confounding factors, results revealed a lower likelihood of treatment success for ICU versus non-ICU subjects, for subjects with persistent neutropenia during therapy, and for subjects with high versus low APACHE II scores. In the logistic regression model including interactions between ICU status and potential confounding factors (where possible), however, the APACHE II score emerged as the only variable associated with each of the four prespecified outcomes analyzed (Table 5). In addition to the APACHE ॥ score, subjects without persistent neutropenia during therapy were more likely to achieve overall treatment success even when interaction terms were included in the final analysis. Similarly, although five explanatory variables (ICU status, primary diagnosis, neutropenia at baseline, diabetes, and APACHE II score) were detected that may have influenced the mycological response on initial analysis, only the APACHE II score

Table 4

\begin{tabular}{|c|c|c|c|c|c|c|c|c|c|}
\hline \multirow[t]{2}{*}{ Outcome } & \multicolumn{2}{|l|}{ Micafungin } & \multicolumn{2}{|c|}{ Liposomal amphotericin B } & \multicolumn{2}{|l|}{$P$ value ${ }^{a}$} & \multicolumn{3}{|l|}{ Total } \\
\hline & $\begin{array}{l}\text { Non-ICU } \\
(n=127)\end{array}$ & $\begin{array}{l}\text { ICU } \\
(n=120)\end{array}$ & $\begin{array}{l}\text { Non-ICU } \\
(n=136)\end{array}$ & $\begin{array}{l}\text { ICU } \\
(n=110)\end{array}$ & Non-ICU & ICU & $\begin{array}{l}\text { Non-ICU } \\
(n=263)\end{array}$ & $\begin{array}{l}\text { ICU } \\
(n=230)\end{array}$ & $P$ value \\
\hline $\begin{array}{l}\text { Overall } \\
\text { treatment } \\
\text { success }\end{array}$ & $108(85.0)$ & $75(62.5)$ & $98(72.1)$ & $73(66.4)$ & $0.0113^{\star}$ & 0.5828 & $206(78.3)$ & $148(64.3)$ & $0.0006^{\star}$ \\
\hline $\begin{array}{l}\text { Mycological } \\
\text { response }\end{array}$ & $109(85.8)$ & 88 (73.3) & $106(77.9)$ & $79(71.8)$ & 0.1115 & 0.8825 & $215(81.7)$ & $167(72.6)$ & 0.2371 \\
\hline $\begin{array}{l}\text { All-cause } \\
\text { mortality at day } \\
8\end{array}$ & $6(4.7)$ & $25(20.8)$ & $14(10.3)$ & $18(16.4)$ & 0.1057 & 0.4028 & $20(7.6)$ & $43(18.7)$ & 0.8935 \\
\hline $\begin{array}{l}\text { All-cause } \\
\text { mortality at day } \\
30\end{array}$ & $25(19.7)$ & 46 (38.3) & 32 (23.5) & $38(34.5)$ & 0.4589 & 0.5852 & $57(21.7)$ & $84(36.5)$ & $0.0003^{\star}$ \\
\hline
\end{tabular}

Data presented as $n(\%)$. ICU, intensive care unit. aMicafungin versus liposomal amphotericin B. *Statistically significant. 


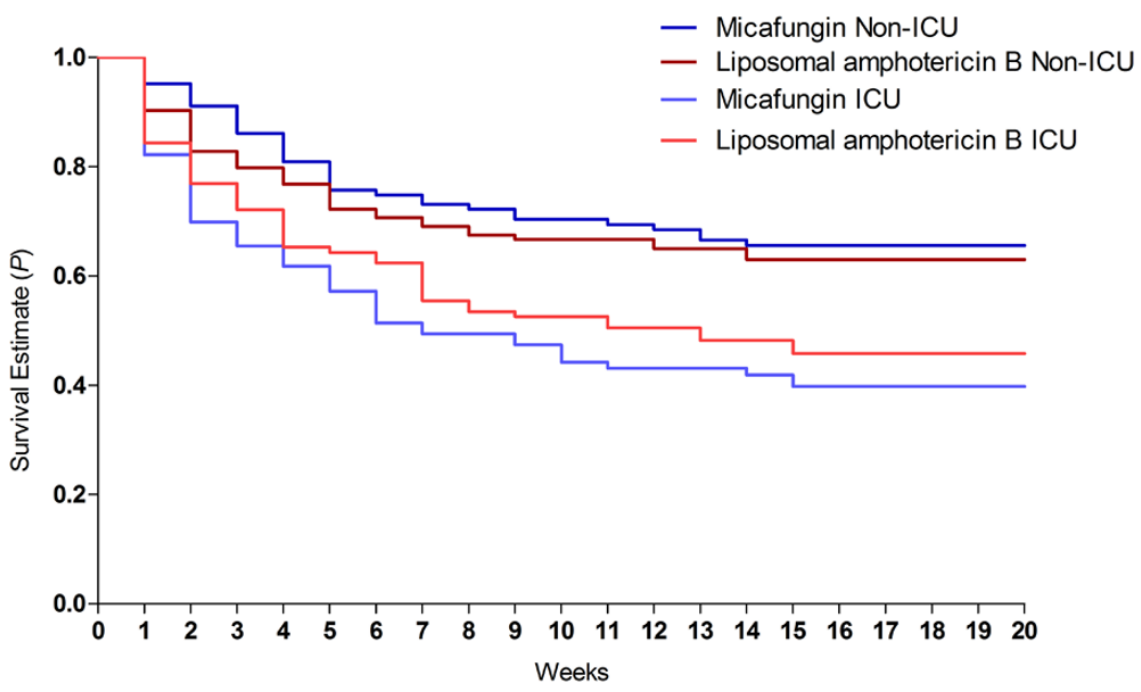

Micafungin versus liposomal amphotericin $\mathrm{B}$ : log rank test $P=0.6840$ ICU versus non-ICU: $\log$ rank test $P<0.0001$

Probability of survival in subjects treated with micafungin and liposomal amphotericin B. Kaplan--Meier estimates of survival in intensive care unit (ICU) subjects and non-ICU subjects.

emerged as a statistically significant explanatory variable associated with mycological response in the final analysis.

Potential explanatory factors demonstrating an association with an increased likelihood of mortality at day 8 were C. $\mathrm{kru}$ sei versus other Candida species and a high versus low APACHE II score. Increasing age, persistent neutropenia, and APACHE II score were associated with a higher likelihood of mortality at day 30 . These associations remained statistically significant when interaction terms were included in the final model.

\section{Safety}

Renal function was significantly better in subjects who received micafungin than those who received liposomal amphotericin B. The difference (liposomal amphotericin B group - micafungin group) in the mean peak change in the estimated glomerular filtration rate was $-18.2 \mathrm{ml} /$ minute $/ 1.73 \mathrm{~m}^{2}$ $(P<0.0001)$ and $-17.7 \mathrm{ml} /$ minute $/ 1.73 \mathrm{~m}^{2}(P=0.0124)$ in non-ICU subjects and in ICU subjects, respectively.

\section{Discussion}

Given that many ICU patients will become infected by one or more Candida spp. at some point during hospitalization [30], it is important that ongoing research is conducted to identify those risk factors that are most likely to influence health outcomes in this multimorbid, heterogeneous patient population.

In this post hoc subgroup analysis of a prospective, randomized clinical trial - conducted in line with various recommen- dations for post hoc analysis [31-35] - the rate of overall treatment success was higher in non-ICU patients receiving micafungin than those receiving liposomal amphotericin $\mathrm{B}$. In ICU patients, overall treatment success rates in patients who received micafungin or liposomal amphotericin $\mathrm{B}$ were similar, and were lower than the corresponding treatment success rates in non-ICU patients.

Although ICU patients had lower treatment success rates than non-ICU patients, multivariate regression analysis revealed that the ICU status was not associated with treatment outcome when potential confounding factors were considered. The APACHE II score was the only potential explanatory variable associated with treatment success, mortality at day 8 , and mortality at day 30. Catheter status had no effect on any outcome in patients with candidemia (data not shown).

These results seem to be at odds with post hoc observations from a prospective randomized study assessing the safety and efficacy of caspofungin versus amphotericin B deoxycholate in patients with invasive candidiasis [36,37]. Multivariate regression analysis indicated that patients initiating antifungal treatment in an ICU were more likely to die than those initiating antifungal therapy outside an ICU even after accounting for APACHE II score [36]. It should be noted, however, that a study of caspofungin versus amphotericin B deoxycholate treatment measured all-cause mortality 6 to 8 weeks after completion of study therapy [36] whereas the analysis we describe here measured all-cause mortality 30 days post treatment initiation. 
Table 5

Significant predictors of overall treatment success, mycological response and mortality

\begin{tabular}{|c|c|c|c|c|}
\hline \multirow[t]{2}{*}{ Variable } & \multirow[t]{2}{*}{ Ratio } & \multirow{2}{*}{$\begin{array}{l}\text { Without interaction } \\
\text { terms }^{\mathrm{a}}\end{array}$} & \multicolumn{2}{|l|}{ With interaction terms } \\
\hline & & & $\begin{array}{l}\text { Maximum likelihood } \\
\text { estimate } \\
( \pm \text { standard error) }\end{array}$ & Wald $\chi^{2}\left(\right.$ probability $\left.>\chi^{2}\right)$ \\
\hline \multicolumn{5}{|l|}{ Overall treatment success } \\
\hline ICU status ${ }^{b}$ & Not in ICU to in ICU & 1.866 (1.147 to 3.034$)$ & $0.1380 \pm 0.5438$ & $0.0644(0.7997)$ \\
\hline Persistent neutropenia & $\begin{array}{l}\text { Non-neutropenic to } \\
\text { neutropenic }\end{array}$ & 5.721 (1.412 to 23.169$)$ & $1.7185 \pm 0.7156$ & $5.7669(0.0163)$ \\
\hline APACHE II score & High to low (continuous) & 0.956 (0.929 to 0.983$)$ & $--0.0468 \pm 0.0144$ & $10.6416(0.011)$ \\
\hline \multicolumn{5}{|l|}{ Mycological response } \\
\hline ICU status ${ }^{b}$ & Not in ICU to in ICU & 1.778 (1.037 to 3.048$)$ & $--0.0223 \pm 1.7567$ & $0.0002(0.9899)$ \\
\hline Primary diagnosis & $\begin{array}{l}\text { Candidemia to invasive } \\
\text { candidiasis }\end{array}$ & 2.465 (1.343 to 4.524$)$ & $0.3246 \pm 0.4368$ & $0.5522(0.4574)$ \\
\hline Neutropenia ${ }^{b}$ & $\begin{array}{l}\text { Non-neutropenic to } \\
\text { neutropenic }\end{array}$ & 2.357 (1.134 to 4.898$)$ & $--0.9093 \pm 1.0206$ & $3.4859(0.0619)$ \\
\hline Diabetes mellitus & No to yes & $0.350(0.137$ to 0.894$)$ & $--1.0113 \pm 0.5362$ & $3.5572(0.0593)$ \\
\hline APACHE II score & High to low (continuous) & 0.953 (0.925 to 0.982$)$ & $--0.0505 \pm 0.0154$ & $10.7417(0.001)$ \\
\hline \multicolumn{5}{|l|}{ All-cause mortality at day 8} \\
\hline Candida spp. & $\begin{array}{l}\text { Candida krusei to other } \\
\text { Candida spp. }\end{array}$ & $3.536(1.039$ to 12.035$)$ & $2.4861 \pm 1.3739$ & $3.2745(0.0704)$ \\
\hline APACHE II score & High to low (continuous) & $1.097(1.055$ to 1.142$)$ & $0.0931 \pm 0.0208$ & $20.0498(<0.0001)$ \\
\hline \multicolumn{5}{|l|}{$\begin{array}{l}\text { All-cause mortality at day } \\
30\end{array}$} \\
\hline Age & Low to high & $1.018(1.003$ to 1.033$)$ & $0.0170 \pm 0.0076$ & $4.9331(0.0263)$ \\
\hline Persistent neutropenia & $\begin{array}{l}\text { Non-neutropenic to } \\
\text { neutropenic }\end{array}$ & 0.160 (0.039 to 0.658$)$ & $--1.7845 \pm 0.7146$ & $6.2358(0.0125)$ \\
\hline APACHE II score & High to low (continuous) & $1.093(1.057$ to 1.131$)$ & $0.0937 \pm 0.0178$ & $27.7797(<0.0001)$ \\
\hline
\end{tabular}

Significant predictors of overall treatment success, mycological response and mortality based on a logistic regression model that controlled for potential confounding variables with and without interaction terms. APACHE, Acute Physiology and Chronic Health Evaluation; ICU, intensive care unit. a Odds ratio ( $95 \%$ confidence interval). ${ }^{b}$ At the time of treatment initiation.

The all-cause mortality rate at day 30 in our analysis was in general agreement with data derived from observational studies [4,38-51]. Using multivariate analyses, findings from observational studies $[4,17,39,42]$ and a prospective clinical trial [52] have underscored the importance of the APACHE II score as a prognostic indicator. In one of the observational studies, graded APACHE II scores were not only strongly associated with 3-month mortality but a linear relationship also existed between these variables for most Candida spp. [39]. Furthermore, analysis of prospective, randomized, controlled trial data clearly demonstrated that the risk of failing study therapy increased incrementally with APACHE II score (odds ratio
$=1.09$ per points, $95 \%$ confidence interval $=1.03$ to $1.14 ; P$ $=0.001$ ) [52].

\section{Conclusions}

While it is important to realize the limitations inherent in any post hoc analysis, the analysis described here remains one of the most extensive such investigations of the associations between the stay in an ICU and clinical outcomes in patients with confirmed candidemia or invasive candidiasis. Our findings underscore the importance of the APACHE II score as a prognostic indicator in both ICU patients and non-ICU patients with invasive Candida infections. 


\section{Key messages}

- In ICU patients, the overall treatment success rates in patients who received micafungin or liposomal amphotericin B were similar, and were lower than the corresponding treatment success rates in non-ICU patients.

- Renal function was significantly better in both ICU and non-ICU patients who received micafungin than in those who received liposomal amphotericin B.

- Multivariate regression analysis, along with the analysis of interactions, revealed that the relationship between the ICU status and treatment outcomes was explained by other variables. The APACHE II score was the only explanatory variable associated with treatment success, all-cause mortality at day 8 , and all-cause mortality at day 30 .

- These data underline the importance of the APACHE II score as a prognostic indicator of clinical outcome in patients receiving antifungal therapy in both the ICU and the non-ICU setting.

\section{Competing interests}

BFD has served as a consultant for Schering-Plough, Astellas Pharma, Merck, Valeant, and BioAlliance. OL has served as a speaker's bureau member for Pfizer, Astellas, Gilead Sciences, Schering Corp and MSD. LO-Z has received research grants, consulting fees, and/or speaker fees from the following companies: Astellas, Merck, Pfizer, Gilead, Sequella, and Basilea. FS is an employee of Astellas Pharma Europe BV, Leiderdorp, The Netherlands. VY has been an investigator in Astellas funded research and serves as a consultant to Astellas Pharma Inc. USA. Sponsored by Astellas Pharma Inc.

\section{Authors' contributions}

BFD, OL, LO-Z, VY were investigators in the clinical trial on which this post hoc analysis is based. FS performed the statistical analysis. All authors contributed to the design of the statistical analysis and reviewed and approved the manuscript at each stage of development.

\section{Acknowledgements}

Additional statistical support was provided by Dorothea Wessiepe of Metronomia Clinical Research GmbH. Medical writing and editorial support was provided by Paul Hassan PhD of Envision Pharma Ltd.

\section{References}

1. Banerjee SN, Emori TG, Culver DH, Gaynes RP, Jarvis WR, Horan T, Edwards JR, Tolson J, Henderson T, Martone WJ: Secular trends in nosocomial primary bloodstream infections in the United States, 1980-1989. National Nosocomial Infections Surveillance System. Am J Med 1991, 91:86S-89S.

2. Beck-Sague C, Jarvis WR: Secular trends in the epidemiology of nosocomial fungal infections in the United States, 19801990. National Nosocomial Infections Surveillance System. J Infect Dis 1993, 167:1247-1251.

3. Antoniadou A, Torres HA, Lewis RE, Thornby J, Bodey GP, Tarrand JP, Han XY, Rolston KV, Safdar A, Raad II, Kontoyiannis DP: Candidemia in a tertiary care cancer center: in vitro susceptibility and its association with outcome of initial antifungal therapy. Medicine (Baltimore) 2003, 82:309-321.

4. Yamamura DL, Rotstein C, Nicolle LE, loannou S: Candidemia at selected Canadian sites: results from the Fungal Disease Registry, 1992-1994. Fungal Disease Registry of the Canadian Infectious Disease Society. CMAJ. 1999, 160:493-499.

5. Ben-Abraham R, Keller N, Teodorovitch N, Barzilai A, Harel R, Barzilay Z, Paret G: Predictors of adverse outcome from candidal infection in a tertiary care hospital. J Infect 2004, 49:317-323.

6. Luzzati R, Amalfitano G, Lazzarini L, Soldani F, Bellino S, Solbiati M, Danzi MC, Vento S, Todeschini G, Vivenza C, Concia E: Nosocomial candidemia in non-neutropenic patients at an Italian tertiary care hospital. Eur J Clin Microbiol Infect Dis 2000, 19:602-607.

7. Voss A, le Noble JL, Verduyn Lunel FM, Foudraine NA, Meis JF: Candidemia in intensive care unit patients: risk factors for mortality. Infection 1997, 25:8-11.

8. Chen YC, Lin SF, Liu CJ, Jiang DD, Yang PC, Chang SC: Risk factors for ICU mortality in critically ill patients. J Formos Med Assoc 2001, 100:656-661.

9. Trick WE, Fridkin SK, Edwards JR, Hajieh RA, Gaynes RP: Secular trend of hospital-acquired candidemia among intensive care unit patients in the United States during 1989-1999. Clin Infect Dis 2002, 35:627-630.

10. Pappas PG, Rex JH, Sobel JD, Filler SG, Dismukes WE, Walsh TJ, Edwards JE: Guidelines for treatment of candidiasis. Clin Infect Dis 2004, 38:161-189.

11. Pfaller MA, Messer SA, Boyken L, Tendolkar S, Hollis RJ, Diekema DJ: Geographic variation in the susceptibilities of invasive isolates of Candida glabrata to seven systemically active antifungal agents: a global assessment from the ARTEMIS Antifungal Surveillance Program conducted in 2001 and 2002. J Clin Microbio/ 2004, 42:3142-3146.

12. Pfaller MA, Messer SA, Hollis RJ, Jones RN, Diekema DJ: In vitro activities of ravuconazole and voriconazole compared with those of four approved systemic antifungal agents against 6,970 clinical isolates of Candida spp. Antimicrob Agents Chemother 2002, 46:1723-1727.

13. Ruan SY, Chu CC, Hsueh PR: In vitro susceptibilities of invasive isolates of Candida species: rapid increase in rates of fluconazole susceptible-dose dependent Candida glabrata isolates. Antimicrob Agents Chemother 2008, 52:2919-2922.

14. Pappas PG, Kauffman CA, Andes D, Benjamin DK, Calandra TF, Edwards JE, Filler SG, Fisher JF, Kullberg BJ, Ostrosky-Zeichner L, Reboli AC, Rex JH, Walsh TJ, Sobel JD: Clinical practice guidelines for the management of candidiasis: 2009 update by the Infectious Diseases Society of America. Clin Infect Dis 2009, 48:503-535.

15. Eggimann P, Garbino J, Pittet D: Management of Candida species infections in critically ill patients. Lancet Infect Dis 2003, 3:772-785.

16. Hughes WT, Armstrong D, Bodey GP, Bow EJ, Brown AE, Calandra T, Feld R, Pizzo PA, Rolston KV, Shenep JL, Young LS: 2002 guidelines for the use of antimicrobial agents in neutropenic patients with cancer. Clin Infect Dis 2002, 34:730-751.

17. Bassetti M, Trecarichi EM, Righi E, Sanguinetti M, Bisio F, Posteraro B, Soro O, Cauda R, Viscoli C, Tumbarello M: Incidence, risk factors, and predictors of outcome of candidemia. Survey in 2 Italian university hospitals. Diagn Microbiol Infect Dis 2007, 58:325-331.

18. Morrell M, Fraser VJ, Kollef MH: Delaying the empiric treatment of Candida bloodstream infection until positive blood culture results are obtained: a potential risk factor for hospital mortality. Antimicrob Agents Chemother 2005, 49:3640-3645.

19. Blot SI, Vandewoude KH, Hoste EA, Colardyn FA: Effects of nosocomial candidemia on outcomes of critically ill patients. Am J Med 2002, 113:480-485.

20. Ibrahim EH, Sherman G, Ward S, Fraser VJ, Kollef MH: The influence of inadequate antimicrobial treatment of bloodstream infections on patient outcomes in the ICU setting. Chest 2000, 118:146-155.

21. Dannaoui E, Lortholary O, Raoux D, Bougnoux ME, Galeazzi G, Lawrence C, Moissenet D, Poilane I, Hoinard D, Dromer F: Comparative in vitro activities of caspofungin and micafungin, determined using the method of the European Committee on Antimicrobial Susceptibility Testing, against yeast isolates 
obtained in France in 2005-2006. Antimicrob Agents Chemother 2008, 52:778-781.

22. Pfaller MA, Boyken L, Hollis RJ, Kroeger J, Messer SA, Tendolkar $S$, Diekema DJ: In vitro susceptibility of invasive isolates of Candida spp. to anidulafungin, caspofungin, and micafungin: six years of global surveillance. J Clin Microbiol 2008, 46:150-156.

23. Pfaller MA, Boyken L, Hollis RJ, Messer SA, Tendolkar S, Diekema $D J$ : Global surveillance of in vitro activity of micafungin against Candida: a comparison with caspofungin by CLSI-recommended methods. J Clin Microbiol 2006, 44:3533-3538.

24. Pfaller MA, Diekema DJ, Gibbs DL, Newell VA, Nagy E, Dobiasova S, Rinaldi M, Barton R, Veselov A: Candida krusei, a multidrugresistant opportunistic fungal pathogen: geographic and temporal trends from the ARTEMIS DISK Antifungal Surveillance Program, 2001 to 2005. J Clin Microbio/ 2008, 46:515-521.

25. Pfaller MA, Diekema DJ, Gibbs DL, Newell VA, Ng KP, Colombo A, Finquelievich J, Barnes R, Wadula J: Geographic and temporal trends in isolation and antifungal susceptibility of Candida parapsilosis: a global assessment from the ARTEMIS DISK Antifungal Surveillance Program, 2001 to 2005. J Clin Microbiol 2008, 46:842-849.

26. Messer SA, Diekema DJ, Boyken L, Tendolkar S, Hollis RJ, Pfaller MA: Activities of micafungin against 315 invasive clinical isolates of fluconazole-resistant Candida spp. J Clin Microbiol 2006, 44:324-326.

27. Richards TS, Oliver BG, White TC: Micafungin activity against Candida albicans with diverse azole resistance phenotypes. $J$ Antimicrob Chemother 2008, 62:349-355.

28. Pappas PG, Rotstein CMF, Betts RF, Nucci M, Talwar D, de Waele JJ, Vazquez JA, Dupont BF, Horn DL, Ostrosky-Zeichner L, Reboli AC, Suh B, Digumarti R, Wu C, Kovanda LL, Arnold L, Buell DN: Micafungin versus caspofungin for treatment of candidemia and other forms of invasive candidiasis. Clin Infect Dis 2007, 45:883-893.

29. Kuse ER, Chetchotisakd P, da Cunha CA, Ruhnke M, Barrios C, Raghunadharao D, Sekhon JS, Freire A, Ramasubramanian V, Demeyer I, Nucci M, Leelarasamee A, Jacobs F, Decruyenaere J, Pittet D, Ullmann AJ, Ostrosky-Zeichner L, Lortholary O, Koblinger $\mathrm{S}$, Diekmann-Berndt $\mathrm{H}$, Cornely $\mathrm{OA}$ : Micafungin versus liposomal amphotericin B for candidaemia and invasive candidosis: a phase III randomised double-blind trial. Lancet 2007, 369:1519-1527.

30. Rangel-Frausto MS, Wiblin T, Blumberg HM, Saiman L, Patterson J, Rinaldi M, Pfaller M, Edwards JE Jr, Jarvis W, Dawson J, Wenzel RP, Group NS: National Epidemiology of Mycoses Survey (NEMIS): variations in rates of bloodstream infections due to Candida species in seven surgical intensive care units and six neonatal intensive care units. Clin Infect Dis 1999, 29:253-258.

31. Assmann SF, Pocock SJ, Enos LE, Kasten LE: Subgroup analysis and other (mis)uses of baseline data in clinical trials. Lancet 2000, 355:1064-1069.

32. Cui L, Hung HM, Wang SJ, Tsong Y: Issues related to subgroup analysis in clinical trials. J Biopharm Stat 2002, 12:347-358.

33. Lagakos SW: The challenge of subgroup analyses - reporting without distorting. N Engl J Med 2006, 354:1667-1669.

34. Moreira ED, Susser E: Guidelines on how to assess the validity of results presented in subgroup analysis of clinical trials. Rev Hosp Clin Fac Med Sao Paulo 2002, 57:83-88.

35. Yusuf S, Wittes J, Probstfield J, Tyroler HA: Analysis and interpretation of treatment effects in subgroups of patients in randomized clinical trials. JAMA 1991, 266:93-98.

36. DiNubile MJ, Lupinacci RJ, Strohmaier KM, Sable CA, Kartsonis NA: Invasive candidiasis treated in the intensive care unit: observations from a randomized clinical trial. J Crit Care 2007, 22:237-244.

37. Mora-Duarte J, Betts R, Rotstein C, Colombo AL, Thompson-Moya L, Smietana J, Lupinacci R, Sable C, Kartsonis N, Perfect J, for the caspofungin invasive candidiasis study group: Comparison of caspofungin and amphotericin $\mathbf{B}$ for invasive candidiasis. $N$ Engl J Med 2002, 347:2020-2029.

38. Horn DL, Fishman JA, Steinbach WJ, Anaissie EJ, Marr KA, Olyaei AJ, Pfaller MA, Weiss MA, Webster KM, Neofytos D: Presentation of the PATH Alliance registry for prospective data collection and analysis of the epidemiology, therapy, and outcomes of invasive fungal infections. Diagn Microbiol Infect Dis 2007, 59:407-414.
39. Pappas PG, Rex JH, Lee J, Hamill RJ, Larsen RA, Powderly W, Kauffman CA, Hyslop N, Mangino JE, Chapman S, Horowitz HW, Edwards JE, Dismukes WE: A prospective observational study of candidemia: epidemiology, therapy, and influences on mortality in hospitalized adult and pediatric patients. Clin Infect Dis 2003, 37:634-643.

40. Tortorano AM, Kibbler C, Peman J, Bernhardt H, Klingspor L, Grillot R: Candidaemia in Europe: epidemiology and resistance. Int J Antimicrob Agents 2006, 27:359-366.

41. Tortorano AM, Peman J, Bernhardt H, Klingspor L, Kibbler CC Faure O, Biraghi E, Canton E, Zimmermann K, Seaton S, Grillot R: Epidemiology of candidaemia in Europe: results of 28-month European Confederation of Medical Mycology (ECMM) hospital-based surveillance study. Eur J Clin Microbiol Infect Dis 2004, 23:317-322.

42. Colombo AL, Guimaraes T, Silva LR, de Almeida Monfardini LP, Cunha AK, Rady P, Alves T, Rosas RC: Prospective observational study of candidemia in Sao Paulo, Brazil: incidence rate, epidemiology, and predictors of mortality. Infect Control Hosp Epidemiol 2007, 28:570-576.

43. Fraser VJ, Jones M, Dunkel J, Storfer S, Medoff G, Dunagan WC: Candidemia in a tertiary care hospital: epidemiology, risk factors, and predictors of mortality. Clin Infect Dis 1992, 15:414-421.

44. Gudlaugsson O, Gillespie S, Lee K, Berg JV, Hu J, Messer S, Herwaldt L, Pfaller M, Diekema D: Attributable mortality of nosocomial candidemia, revisited. Clin Infect Dis 2003, 37:1172-1177.

45. Komshian SV, Uwaydah AK, Sobel JD, Crane LR: Fungemia caused by Candida species and Torulopsis glabrata in the hospitalized patient: frequency, characteristics, and evaluation of factors influencing outcome. Rev Infect Dis 1989, 11:379-390.

46. Morgan J, Meltzer MI, Plikaytis BD, Sofair AN, Huie-White S, Wilcox S, Harrison LH, Seaberg EC, Hajjeh RA, Teutsch SM: Excess mortality, hospital stay, and cost due to candidemia: a casecontrol study using data from population-based candidemia surveillance. Infect Control Hosp Epidemiol 2005, 26:540-547.

47. Poikonen E, Lyytikainen O, Anttila VJ, Ruutu P: Candidemia in Finland, 1995-1999. Emerg Infect Dis 2003, 9:985-990.

48. Puzniak L, Teutsch S, Powderly W, Polish L: Has the epidemiology of nosocomial candidemia changed? Infect Control Hosp Epidemiol 2004, 25:628-633.

49. Viscoli C, Girmenia C, Marinus A, Collette L, Martino P, Vandercam B, Doyen C, Lebeau B, Spence D, Krcmery V, De Pauw B, Meunier F: Candidemia in cancer patients: a prospective, multicenter surveillance study by the Invasive Fungal Infection Group (IFIG) of the European Organization for Research and Treatment of Cancer (EORTC). Clin Infect Dis 1999, 28:1071-1079.

50. Wey SB, Mori M, Pfaller MA, Woolson RF, Wenzel RP: Hospitalacquired candidemia. The attributable mortality and excess length of stay. Arch Intern Med 1988, 148:2642-2645.

51. Zaoutis TE, Argon J, Chu J, Berlin JA, Walsh TJ, Feudtner C: The epidemiology and attributable outcomes of candidemia in adults and children hospitalized in the United States: a propensity analysis. Clin Infect Dis 2005, 41:1232-1239.

52. Rex JH, Pappas PG, Karchmer AW, Sobel J, Edwards JE, Hadley S, Brass C, Vazquez JA, Chapman SW, Horowitz HW, Zervos M, McKinsey D, Lee J, Babinchak T, Bradsher RW, Cleary JD, Cohen DM, Danziger L, Goldman M, Goodman J, Hilton E, Hyslop NE, Kett DH, Lutz J, Rubin RH, Scheld WM, Schuster M, Simmons B, Stein DK, Washburn RG, et al:: A randomized and blinded multicenter trial of high-dose fluconazole plus placebo versus fluconazole plus amphotericin B as therapy for candidemia and Its consequences in nonneutropenic subjects. Clin Infect Dis 2003, 36:1221-1228. 